\title{
Local Antibacterial Implant Protection in Orthopedics and Trauma: What's New?
}

\author{
C.L. Romanò ${ }^{1,2}$, S. Bozhkova ${ }^{3}$, V. Artyukh ${ }^{3}$, D. Romanò ${ }^{1}$, H. Tsuchiya ${ }^{4}$, L. Drago $^{5}$ \\ ${ }^{1}$ Studio Medico Cecca-Romanò, Milan, Italy \\ ${ }^{2}$ Romano Institute, Tirane, Albania \\ ${ }^{3}$ Vreden Russian Research Institute of Traumatology and Orthopedics, St. Petersburg, Russian Federation \\ ${ }^{4}$ Graduate School of Medical Science, Kanazawa University, Kanazawa, Japan \\ ${ }^{5}$ Clinical Microbiology, University of Milan, Milan, Italy
}

\begin{abstract}
Current prophylactic and hygienic measures notwithstanding, implant-related infection remains among leading reasons for failure in orthopaedics and trauma surgery, resulting in extremely high social and economic costs. Various antibacterial coating technologies have been proven safe and effective both in preclinical and in clinical settings and able to reduce post-surgical infections up to $90 \%$, depending on the type of the coating and on the experimental setup. In spite of this findings, the widespread use of these technologies is still limited by several factors. After reviewing the latest evidence on currently available antibacterial coatings, an algorithm is proposed to calculate the impact of the delayed introduction of these technologies in the clinical practice. When applied to joint arthroplasties, our calculator shows that each year of delay to implement an antibacterial coating, able to reduce post-surgical infection by $80 \%$ at a final user's cost price of $€ 600$, causes an estimated 35200 new cases of periprosthetic joint infection in Europe and additional annual hospital costs of approximately $€ 440$ million. Faster and more affordable regulatory pathways for antibacterial coating technologies and an adequate reimbursement policy for their clinical use appear a feasible solution to mitigate the impact of implant-related infections and may benefit patients, healthcare systems, and related research.
\end{abstract}

Keywords: infection, prosthesis, implant coating, periprosthetic joint infection, PJI.

doi: $10.21823 / 2311-2905-2019-25-4-64-74$

\section{Применение имплантатов с антибактериальным покрытием в ортопедии и травматологии: современное состояние проблемы}

\author{
К.Л. Романо ${ }^{1,2}$, С. Божкова ${ }^{3}$, В. Артюх ${ }^{3}$, Д. Романо ${ }^{1}$, Х. Цучия ${ }^{4}$, Л. Драго ${ }^{5}$ \\ ${ }^{1}$ Медицинская клиника Сесса-Roтапо̀, Милан, Италия \\ ${ }^{2}$ Медицинская клиника Romano Institute, Тирана, Албания \\ ${ }^{3}$ ФГБУ «Российский научно-исследовательский институт травматологии и ортопедии им. Р.P. Вредена» \\ Минздрава России , Санкт-Петербург, Россия \\ ${ }^{4}$ Высшая школа медицины, Университет Канадзавы, Канадзава, Япония \\ ${ }_{5}^{5}$ Факультет клинической микробиологии, Миланский университет, Милан, Италия
}

\section{Реферат}

Несмотря на современные достижения профилактики и гигиены, имплант-ассоциированная инфекция остается одной из основных причин несостоятельных результатов ортопедических и травматологических вмешательств, что приводит к чрезвычайно высоким социальным и экономическим издержкам. Различные технологии антибактериального покрытия имплантатов зарекомендовали себя как безопасное и эффектив-

[D] Cite as: Romanò C.L., Bozhkova S., Artyukh V., Romanò D., Tsuchiya H., Drago L. Local Antibacterial Implant Protection in Orthopedics and Trauma: What's New? Travmatologiya i ortopediya Rossii [Traumatology and Orthopedics of Russia]. 2019;25(4):64-74. doi: 10.21823/2311-2905-2019-25-4-64-74.

$\triangle$ Carlo L. Romanò; e-mail: carlo.romano@unimi.it

Received: 11.08.2019. Accepted for publication: 22.09.2019. 
ное решение проблемы инфицирования в процессе как доклинических исследований, так и в клинической практике, что способствует снижению частоты послеоперационной инфекции до 90\% в зависимости от типа покрытия и условий использования. Несмотря на такие выводы, широкое внедрение подобных технологий по-прежнему ограничено несколькими факторами. Изучив наиболее актуальные данные по доступным антибактериальным покрытиям, авторы предлагают алгоритм для расчета влияния несвоевременного внедрения таких технологий в клиническую практику. Применение предлагаемого калькулятора к операциям по эндопротезированию суставов демонстрирует, что каждый год отсрочки внедрения антибактериальных покрытий, который позволил бы снизить частоту послеоперационной инфекции на $80 \%$ при стоимости для конечного пользователя в размере 600 евро, приведет примерно к 35200 новых случаев возникновения перипротезной инфекции в странах Европы и к дополнительным ежегодным госпитальным расходам в размере около 440 млн евро. Ускоренные и более доступные с точки зрения затрат процессы нормативного регулирования в отношении технологий антибактериального покрытия имплантатов, а также адекватная политика возмещения расходов по клиническому использованию таких технологий представляются возможным решением для снижения частоты имплант-ассоциированной инфекции, улучшения качества лечения пациентов, снижения нагрузки на систему здравоохранения и для стимулирования научных изысканий.

Ключевые слова: эндопротезирование, имплантаты, антибактериальное покрытие, перипротезная инфекция, расходы на лечение.

\section{Relevance}

Approximately 2 million joint arthroplasties are performed annually in Europe [1], while osteosynthesis for long bone fractures shows similar figures [2]. Undoubtedly, these numbers reflect the high success of biomaterials and related technologies in orthopedics and trauma in the last decades. However, even if the routine use of biomaterials has been pivotal in reducing the burden of disability worldwide, the long-term durability of implants is not guaranteed, and infection remains one of the main reasons for failure. In fact, considering high risk and oncological cases, periprosthetic joint infection (PJI) affects between $0.5 \%$ and $15 \%$ of patients undergoing primary or revision joint arthroplasty [3, 4]. Similarly, surgical site infection (SSI) after internal osteosynthesis for closed fracture has a reported incidence ranging from $0.5 \%$ to $10 \%$ $[5,6,7,8]$, and up to $50 \%$ after open fractures [9]. In line with this figures, SSI following spine surgery occurs in $1 \%$ to $14 \%$ of patients, depending on the preoperative diagnosis and type of surgery $[10,11]$.

The economic and social costs of implant-related infections are significant $[12,13,14,15]$, with high morbidity and a possible increase in mortality [6], In particular, direct hospital costs, related to the management of PJI, range from approximately $€ 20000$ to $€ 60000$, while the long-term economic effect of post-surgical infection after joint arthroplasty has been calculated to exceed US $\$ 390000$ per case $[16,17,18,19,20,21,22,23,24]$.

\section{Rationale for local antibacterial implant protection}

Whenever a biomaterial is implanted, a competition for surface colonization starts between the host's and the bacterial cells, that may eventually be present. Whenever the bacteria adhere to the implant, immediate biofilm formation takes place, making the microorganisms extremely resistant to host's defense mechanisms and to antimicrobials [25, 26, 27, 28, 29]. The colonization of the implant from the bacteria is then decided at the very time of surgery, even if the clinical consequences, the "post-surgical infection", may become evident only weeks, months or even years after surgery, depending on the relative balance between the microorganisms and the host's individual inflammatory response.

This observation grounds the basis for protecting the implant at the very time of surgery with surface finishing or coatings specifically designed to selectively prevent bacterial adhesion and biofilm formation, without interfering with the biocompatibility and the long-term duration and function of the implant [30].

Various technologies have been investigated in the last decades and can be classified according to their mechanism of action as follows [31] (Table 1):

- Passive surface finishing/modification: this approach aims at preventing or reducing bacterial adhesion to implants through surface chemistry and/or physical modifications, without the use of any pharmacologically active substance. Examples of this approach include modified titanium dioxide surface or polymer coatings.

- Active surface finishing/modification: pharmacologically active pre-incorporated bactericidal agents, such as antibiotics, antiseptics, metal ions, or other organic and inorganic substances, are actively released from the implant in order to reduce bacterial adhesion. Examples of this approach are "contact killing" active surface with silver- or iodine-coated joint implants.

- Local carriers or coatings: this strategy employs local antibacterial carriers, or coatings, that are not built into the device, but rather are applied during surgery, immediately prior to the insertion of the implant. They may have direct or synergistic antibacterial/antiadhesive activity or may deliver high local concentrations of loaded antibiotics or antibacterial agents. 


\section{Classification of antibacterial implant protection strategies [31]}

\begin{tabular}{|c|c|}
\hline Features/examples & Development stage \\
\hline \multicolumn{2}{|l|}{ Passive Surface/Finishing Modifications (PSM) } \\
\hline \multicolumn{2}{|l|}{ Prevention of bacterial adhesion } \\
\hline Hydrophilic surface & Preclinical \\
\hline Superhydrophobic surface & Preclinical \\
\hline Anti-adhesive polymers & Preclinical \\
\hline Nanopatterned surface & Preclinical \\
\hline Albumin & Preclinical \\
\hline Hydrogels & Preclinical \\
\hline Biosurfactants & Preclinical \\
\hline \multicolumn{2}{|l|}{ Active Surface/Finishing Modifications (ASM) } \\
\hline \multicolumn{2}{|l|}{ Inorganic } \\
\hline silver ions and nanoparticles & Market \\
\hline other metals (copper, zinc, titanium dioxide, etc.) & Preclinical \\
\hline non-metals: iodine & Clinical \\
\hline other non-metal ions (selenium, graphene, etc.) & Preclinical \\
\hline \multicolumn{2}{|l|}{ Organic } \\
\hline coated/linked antibiotics & Market \\
\hline covalently linked antibiotics & Preclinical \\
\hline antimicrobial peptides & Preclinical \\
\hline cytokines & Preclinical \\
\hline enzymes and biofilm-disrupting agents & Preclinical \\
\hline chitosan derivatives & Preclinical \\
\hline \multicolumn{2}{|l|}{ Synthetic } \\
\hline non-antibiotic antimicrobial compounds & Preclinical \\
\hline “smart” coatings & Preclinical \\
\hline \multicolumn{2}{|l|}{ Combined } \\
\hline multilayer coating & Preclinical \\
\hline \multicolumn{2}{|l|}{ Local Carriers or Coatings (LCC) } \\
\hline $\begin{array}{l}\text { Non-biodegradable } \\
\text { antibiotic-loaded poly (methyl methacrylate) }\end{array}$ & Market \\
\hline \multicolumn{2}{|l|}{ Biodegradable } \\
\hline antibiotic-loaded bone grafts and substitutes & Market \\
\hline $\begin{array}{l}\text { fast-resorbable hydrogel (acting both as passive surface modification system } \\
\text { and as local antibiotic carrier) }\end{array}$ & Market \\
\hline
\end{tabular}


In spite of several products found effective at a research level, translating preclinical findings into clinical practice appears particularly challenging, timeconsuming, and expensive. As a result, many promising coating technologies fail to reach the market due to regulatory, commercial or economic restrictions, with a loss of chance for the patients and for the health care systems, which is difficult to quantify [32].

\section{Antibacterial coating of implants: current technologies}

Besides antibiotic-loaded poly(methyl methacrylate) (PMMA), bone grafts, and calcium-based bone substitutes that, even if adopted in the clinical setting, were not specifically designed to act as antimicrobial coatings of implants, only four technologies are currently available in orthopedics and trauma for clinical use, or at least with reported clinical results [33]. These include silver and iodine coatings, gentamicin poly(D, L-lactide) (PLLA) coating, and a fastresorbable hydrogel coating composed of covalently linked hyaluronan and PLLA (Defensive Antibacterial Coating (DAC $\left.{ }^{\circledR}\right)$; Novagenit Srl, Mezzolombardo, Italy) (Table 2).

\section{Silver coatings}

Silver antibacterial activity is known since ancient ages. Silver dissolved cations are capable of interfering with bacterial cell membrane permeability and cellular metabolism and, when released in an aqueous medium, contribute to the formation of reactive oxygen species that potentially influence prokaryotic cells [33]. Different technologies are currently used to apply the silver coating to metallic orthopaedic implants [33, 34, 35]. Comparative and prospective studies are not available and only retrospective case series have been published, with coating application restricted to tumour prostheses [36, 37].

Wafa et al. [38] reported the results of silver-coated tumour prostheses in 85 patients compared with 85 matched control patients. Indications included 50 primary reconstructions (29.4\%), 79 one-stage revisions (46.5\%), and 41 two-stage revisions for infection (24.1\%). At a minimum follow-up of 12 months, there was a significant reduction in the overall postoperative infection rate from $22.4 \%$ to $11.8 \%(p=0.03)$ in favour of the silver-coated implant group, with a mean reduction of approximately $48 \%$ in infection rate.

Comparison of clinically available antimicrobial coating technologies, specifically designed for orthopaedics and trauma implants

\begin{tabular}{|c|c|c|c|c|}
\hline Technology & $\begin{array}{l}\text { Regulatory } \\
\text { phase }\end{array}$ & $\begin{array}{l}\text { Trademark and manufacture } \\
\text { company }\end{array}$ & $\begin{array}{l}\text { Mechanism } \\
\text { of action }\end{array}$ & Main applications \\
\hline Silver & Market & $\begin{array}{l}\text { Agluna }{ }^{\circledR} \text { (Accentus Medical Ltd, } \\
\text { Didcot, United Kingdom); Mutars } \\
\text { (Implantcast GmbH, Buxtehude, } \\
\text { Germany); PorAg (Waldemar } \\
\text { Link GmbH \& Co. KG, Hamburg, } \\
\text { Germany) }\end{array}$ & $\begin{array}{l}\text { Silver ion } \\
\text { release }\end{array}$ & $\begin{array}{l}\text { Tumour } \\
\text { mega-prosthesis }\end{array}$ \\
\hline Iodine & $\begin{array}{l}\text { Clinical } \\
\text { trials }\end{array}$ & Not applicable & Iodine release & $\begin{array}{l}\text { Titanium implants } \\
\text { including spine } \\
\text { instrumentation, } \\
\text { hip and knee joint } \\
\text { arthroplasties, plates } \\
\text { and screws }\end{array}$ \\
\hline $\begin{array}{l}\text { Gentamicin } \\
\text { poly(D, } \\
\text { L-lactide) matrix }\end{array}$ & Market & $\begin{array}{l}\text { UTN PROtect Tibial Nail }{ }^{\circledR} \text { (DePuy } \\
\text { Synthes, Bettlach, Switzerland); } \\
\text { Expert Tibial Nail (ETN) PROtect }{ }^{\circledR} \\
\text { (DePuy Synthes, Johnson \& } \\
\text { Johnson, New Brunswick, New } \\
\text { Jersey) }\end{array}$ & $\begin{array}{l}\text { Gentamicin } \\
\text { release }\end{array}$ & $\begin{array}{l}\text { Tibial nail } \\
\text { for the treatment } \\
\text { of tibial fractures } \\
\text { and nonunions }\end{array}$ \\
\hline $\begin{array}{l}\text { Hyaluronic acid } \\
\text { and poly(D, } \\
\text { L-lactide) } \\
\text { hydrogel }\end{array}$ & Market & $\begin{array}{l}\text { Defensive Antibacterial } \\
\text { Coating (DAC }{ }^{\circledR} \text { ) (Novagenit Srl, } \\
\text { Mezzolombardo, Italy) }\end{array}$ & $\begin{array}{l}\text { Antifouling } \\
\text { activity with } \\
\text { ancillary } \\
\text { antibiotic } \\
\text { release }\end{array}$ & $\begin{array}{l}\text { Orthopaedics, } \\
\text { traumatology, } \\
\text { dentistry, and } \\
\text { maxillofacial } \\
\text { implants }\end{array}$ \\
\hline
\end{tabular}


The routine use of silver-coated implants remains rather limited for several reasons, including possible toxicity of silver ions [39], and incomplete protection of the implant, since the intramedullary part of the prosthesis and some modular components cannot be coated. Moreover, only a few implant designs are offered with silver coating protection, while the cost of the technology remains quite high when considering applications outside oncology [40].

\section{Iodine coating}

Povidone-iodine can be used as an electrolyte, resulting in the formation of an adhesive, porous anodic oxide with the antiseptic properties of iodine [41]. Besides extensive preclinical studies [41, 42, 43], excellent clinical efficacy was reported for iodine coating of titanium alloys in a continuous, noncomparative series of 222 patients [44]. Preoperative diagnoses included tumour in 95 cases $(42.8 \%)$, 34 limb deformities (15.3\%), 29 cases of degen- erative disease (13.1\%), 27 osteomyelitis (12.2\%), 24 nonunions (10.8\%), and 16 fractures $(7.2 \%)$. A variety of implants were used: 82 spinal instrumentations, 55 plates for osteosynthesis, 36 external fixations (pins and wires), 32 tumour prostheses, ten hip prostheses, four knee prostheses, two nails, and one cannulated screw. At a mean follow-up of 18.4 months (3 to 44), acute infection developed in three tumour cases $(1.9 \%)$.

Two more recent non-comparative studies - one investigating iodine coating and megaprosthesis [45], the other investigating total hip arthroplasty (THA) [46] - confirmed the safety and efficacy of the technology at longer follow-ups. Based on these findings, clinical trials are currently ongoing to meet the regulatory requirements for market approval (Fig. 1). While no adverse event has been reported to date, the longer-term effects of local application of iodine coating and the application to materials other than titanium are yet to be assessed.
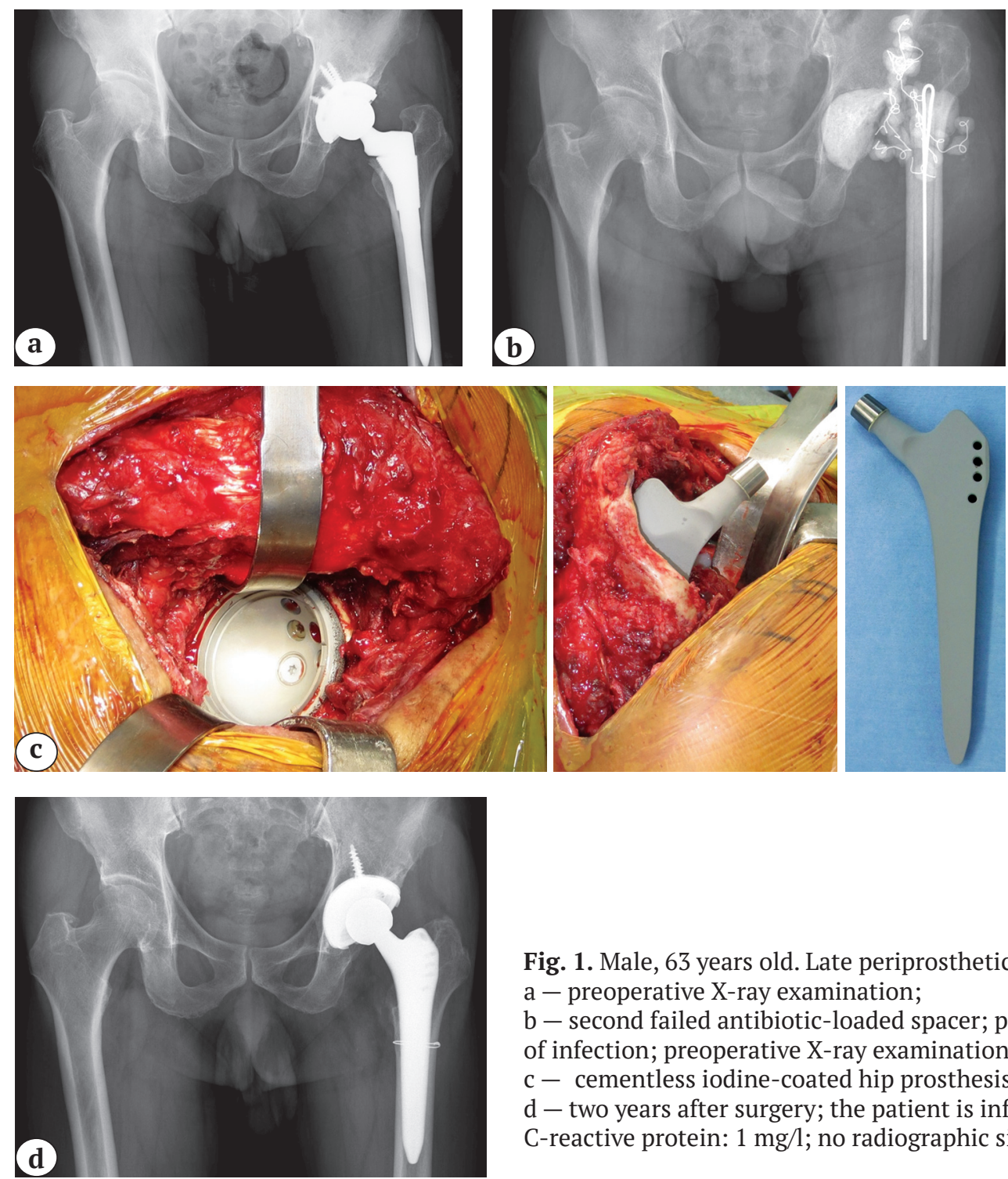

Fig. 1. Male, 63 years old. Late periprosthetic joint infection:

a - preoperative X-ray examination;

$\mathrm{b}$ - second failed antibiotic-loaded spacer; persistence

of infection; preoperative X-ray examination;

c - cementless iodine-coated hip prosthesis; intra-operative pictures;

$\mathrm{d}-$ two years after surgery; the patient is infection free;

C-reactive protein: $1 \mathrm{mg} / \mathrm{l}$; no radiographic signs of implant loosening 


\section{Gentamicin PLLA coating}

A coating for tibial nails, composed of a poly-1lactic acid (PLLA) matrix, loaded with gentamicin, was first introduced into clinical use in Europe approximately fifteen years ago. The coating provides $80 \%$ release of the antibiotic within the first 48 hours [47]. In the first published clinical report, Fuchs et al. [48] observed no deep infections at six months' follow-up in 21 patients treated with a UTN PROtect Tibial Nail (DePuy Synthes, Bettlach, Switzerland) for closed or open tibial fractures, as well as for revisions. Metsemakers et al. [49] reported a retrospective analysis, including nine patients with a Gustilo and Anderson grade II or grade III open tibial fracture, four infected nonunions, two acute tibial shaft fractures pretreated with external fixation, and one aseptic nonunion with a soft tissue defect. At 18 months' follow-up, no implant-associated deep infection was reported. Finally, in the most recent and largest study, data from four centres, analyzed the outcome of 99 patients with fresh open or closed tibial fractures or undergoing nonunion revision surgery [50]. At 18 months' follow-up, deep surgical site infection or osteomyelitis was noted in $4 / 55$ patients (7.2\%) after fresh fracture and in $2 / 26$ patients (7.7\%) after revision surgery. The heterogeneous material and the lack of a comparator makes the interpretation of these results particularly difficult.

Apart from the absence of comparative trials, a limit of this technology is the fact that it is only available for the tibia and for one specific nail design. Furthermore, screws and fixation holes are not protected by the coating, while gentamicin resistance, ranging from $2 \%$ to $50 \%$ in Europe [51], may reduce the efficacy of the coating in some cases.

\section{D.A.C. hydrogel}

The Defensive Antibacterial Coating (D.A.C.) hydrogel is the first antimicrobial coating specifically designed to protect a variety of biomaterials in orthopedics, traumatology, dentistry, and maxillofacial surgery $[52,53]$. The device is based on the ability of hyaluronic-based compounds to reduce bacterial adhesion and biofilm formation, and to protect against various infectious agents $[54,55,56]$. Although designed as a stand-alone product, the DAC hydrogel is capable of entrapping several antibacterial agents at concentrations ranging from $2 \%$ to $10 \%$, released locally for up to 72 hours, with an amount of drug released that is hundreds or thousands of times higher than the minimum inhibitory concentration (MIC), in a time- and dose-dependent manner [52]. This is why, according to the classification mentioned earlier, the DAC hydrogel features and intermediate mechanism of action and can both be classified as a Passive Surface Modification and as a Local Antibiotic Carrier.

The safety and efficacy of DAC hydrogel have been tested in several preclinical in vitro and in vivo studies $[57,58,59]$. Clinically, a first multicenter, randomized prospective trial was conducted in Europe, on a total of 380 patients, scheduled to undergo primary or revision hip or knee joint arthroplasty [60]. Overall, 373 patients were available at a mean followup of 14.5 months (sd 5.5). A total of 11 SSIs were observed in the control group, with only one observed in the treatment group ( $6 \%$ vs $0.6 \% ; p=0.003$ ). No local or systemic side effects related to the DAC hydrogel coating were reported, and no detectable interference with implant osteointegration was noted. In another multicentre prospective study, 256 patients undergoing osteosynthesis for a closed fracture were randomly assigned to receive the antibiotic-loaded DAC coating or to a control group without coating. At a mean follow-up of 18.1 months (sd 4.5), six SSIs (4.6\%) were observed in the control group compared with none in the treated group $(p<0.02)$. No local or systemic side effects related to DAC hydrogel coating were observed, and no detectable interference with bone healing was reported [61]. More recently, DAC hydrogel-coated cementless was tested safe for onestage exchange for infected prosthesis (Fig. 2) [62]. However, longer-term data are required to examine delayed or late prosthetic joint infections. In fact, while the quick resorption of the hydrogel makes long-term side effects quite unlikely, this same feature may limit or prevent the ability of this technology to protect the implant from late, haematogenous infections. 

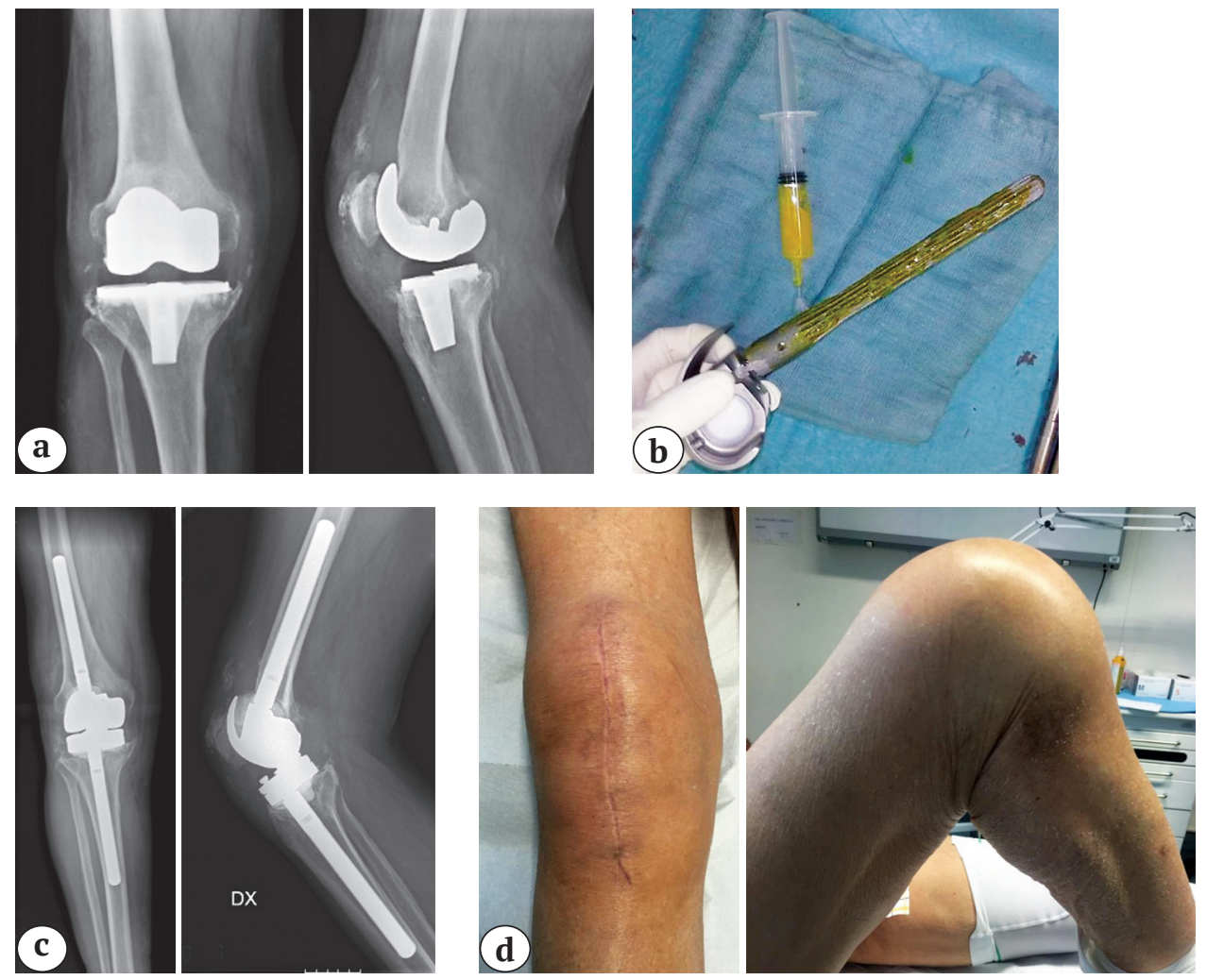

Fig. 2. Male, 82 years old. Delayed periprosthetic knee infection. Failed debridement and irrigation and prolonged suppressive antibiotic therapy. Multi-resistant Staph. Aureus. Joint instability due to severe medial ligaments insufficiency:

a - pre-operative X-ray examination;

b - intra-operative picture, at the time of "one-stage" knee revision surgery; based on pre-operative antibiogram, tigecycline-loaded Defensive Antibacterial Coating hydrogel is applied on the cementless stem of the revision implant; c - radiographic control, two years after surgery; no sign of osteolysis or loosening;

$\mathrm{d}$ - clinical images at two years from revision surgery; no signs of infection recurrence and full function recovery; the patient has just been operated on the contralateral knee for osteoarthritis

\section{Potential impact of large-scale application of antibacterial coatings}

Implementing measures against post-surgical infection after joint arthroplasty may result in a measurable reduction of PJI, with significant cost saving and improved quality of life.

According to Graves et al. [63], considering a cohort of 77321 patients undergoing primary total hip replacement in the United Kingdom, a combined treatment strategy able to reduce post-surgical infection (odds ratio 0.13) may prevent 1481 cases of deep infection, leading to annual cost savings of $£ 8325277$, when compared with a baseline strategy (plain cement, conventional ventilation, and no systemic antibiotics).

Shearer et al. [64] calculated that the net monetary benefit resulting from a $10 \%$ reduction in PJIs was $\$ 278$ per index procedure and concluded that strategies aimed at reducing PJI may have a greater effect on cost and long-term effectiveness of THA than further enhancements in implant longevity.
Our group recently proposed an algorithm to calculate the cost-effectiveness of different antibacterial coating strategies applied to joint prostheses, taking both direct and indirect hospital costs into account [40]. According to this model, an antibacterial coating technology able to reduce post-surgical infection by $80 \%$, at a cost per patient of $€ 600$, would provide a reduction in hospital costs of $€ 200$ per patient if routinely applied in a population that would otherwise have an expected post-surgical infection rate of $2 \%$. Projecting these figures at a European level, with approximately 2.2 million joint arthroplasties performed per year, we may speculate that a year of delay in the routine use of such a coating would result in 35200 additional PJI cases per year with additional annual costs of approximately $€ 440$ million per year (Table 3 and 4) [65]. These calculations do not include any costs that might result from an increased mortality rate, permanent disability deriving from post-surgical infection, or medicolegal claims. 
Algorithm to calculate the economic impact of an antibacterial coating of joint arthroplasty; a positive balance indicates that, for the selected parameters, the ABC technology is associated with a net cost saving, a negative value would indicate a net economic loss [40]

\begin{tabular}{|c|c|c|}
\hline & No coating & $\mathrm{ABC}$ \\
\hline Joint replacement, average cost per patient & \multicolumn{2}{|r|}{ a } \\
\hline Joint arthroplasties per year, $\mathrm{n}$ & \multicolumn{2}{|r|}{$\mathrm{b}$} \\
\hline Total cost of joint arthroplasties per year & \multicolumn{2}{|r|}{$c=a^{*} b$} \\
\hline $\mathrm{ABC}$ cost per patient & 0 & d \\
\hline$\%$ of expected PJI & \multicolumn{2}{|r|}{ e } \\
\hline \% reduction of $\mathrm{PJI}$ with $\mathrm{ABC}$ & \multicolumn{2}{|r|}{$\mathrm{f}$} \\
\hline Expected infections, $\mathrm{n}$ & $g=b^{*}(e / 100)$ & $h=b^{*}(e / 100)^{*}(1-f / 100)$ \\
\hline PJI treatment, cost per case & \multicolumn{2}{|r|}{$\mathrm{i}$} \\
\hline Costs per all septic complication treatment & $k=g^{*} \mathrm{i}$ & $l=h * i$ \\
\hline Costs for joint arthroplasty including septic complications & $\mathrm{m}=\mathrm{c}+\mathrm{k}$ & $\mathrm{n}=\mathrm{c}+\mathrm{l}$ \\
\hline Total costs for $\mathrm{ABC}$ & & $o=b^{*} d$ \\
\hline Total costs & $\mathrm{p}=\mathrm{m}$ & $q=n+o$ \\
\hline Balance & \multicolumn{2}{|r|}{$r=p-q$} \\
\hline \% Balance (Total costs with $A B C /$ without) & \multicolumn{2}{|r|}{$r^{\prime}=q / p$} \\
\hline
\end{tabular}

$\mathrm{ABC}$ - antibacterial coating; PJI - prosthetic joint infection.

Simulation of the algorithm application to a cohort of 2.2 million patients, approximately equivalent to the number of total joint replacements performed each year in Europe.

According to this scenario, the routine use of the coating would be associated to annual costs savings of $€ 440000000$ and 8000 new cases of PJI, compared to 44000 new cases of PJI if the coating is not used

\begin{tabular}{|c|c|c|}
\hline & No coating & $\mathrm{ABC}$ \\
\hline Joint arthroplasty, average cost per patient & \multicolumn{2}{|c|}{$€ 8000$} \\
\hline Joint arthroplasties per year, number & \multicolumn{2}{|c|}{2200000} \\
\hline Total cost of joint arthroplasties per year & \multicolumn{2}{|c|}{$€ 17600000000$} \\
\hline $\mathrm{ABC}$ cost per patient & $€ 0$ & $€ 600$ \\
\hline \% of expected PJI (without the coating) & \multicolumn{2}{|c|}{2,0} \\
\hline \% reduction of $\mathrm{PJI}$ with $\mathrm{ABC}$ & \multicolumn{2}{|c|}{80} \\
\hline Expected infections, number & 44000,0 & 8800,0 \\
\hline PJI treatment, cost per case & \multicolumn{2}{|c|}{$€ 50000$} \\
\hline Costs per all septic complication treatment & $€ 2200000000$ & $€ 440000000$ \\
\hline Costs for joint arthroplasty including septic complications & $€ 19800000000$ & $€ 18040000000$ \\
\hline Total costs for $\mathrm{ABC}$ & & $€ 1320000000$ \\
\hline Total costs & $€ 19800000000$ & $€ 19360000000$ \\
\hline Balance & \multicolumn{2}{|c|}{$+€ 440000000$} \\
\hline \% Balance (Total costs with $A B C /$ without) & \multicolumn{2}{|c|}{97,8} \\
\hline
\end{tabular}

$\mathrm{ABC}$ - antibacterial coating; PJI - prosthetic joint infection. 


\section{Conclusions}

Implant-related infections in orthopedics and trauma have a tremendous social and economic impact projected to grow over the next decades and associated with increased rates of morbidity and mortality. Despite the recognized need for implant-related infection containment and the demonstrated efficacy of some antibacterial coatings notwithstanding, only a few technologies are currently available in orthopaedics and trauma.

Given the potential benefits that can be anticipated scientifically by a wider application of antibacterial implant coating technologies, in our opinion, any effort should be made to increase the awareness of health care providers and their patients concerning the existing technologies and their possible contribution to mitigate septic complication; furthermore, specific reimbursements for the currently available coatings should be introduced, with faster and more affordable regulatory pathways for the most promising technologies in the pipeline. At the same time, an efficient and independent post-marketing surveillance system need to be set at national or international level, in order to monitor the clinical results and promptly report on any possible side effect or long-term complication of such new technologies.

\section{Publication ethics}

All patients provided written informed consent.

Competing interests: the authors declare that there are no competing interests.

Funding: no funding or sponsorship was received for this study or publication of this article.

\section{Authors' contribution}

C.L. Romanò - conceived and drafted the manuscript.

S.A.Bozhkova - design and revision the manuscript.

V. Artyukh - literature review.

D. Romanò - bibliographic search, manuscript revision.

H. Tsuchiya - manuscript revision, figure and case presentation.

L. Drago - co-drafted the manuscript.

\section{References}

1. Organisation for Economic Co-operation and Development (OECD), European Commission. Hip and knee replacement. In: Health at a Glance: Europe 2016: State of Health in the EU Cycle. Paris: OECD Publishing, 2016. pp. 172-173.

2. Papin P., Berthonnaud E. Incidence of osteosynthesis of members in France. Int Orthop. 2017;41(8):1501-1506. doi: 10.1007/s00264-017-3502-6.

3. Cats-Baril W., Gehrke T., Huff K., Kendoff D., Maltenfort M., Parvizi J. International consensus on periprosthetic joint infection: description of the consensus pro- cess. Clin Orthop Relat Res. 2013;471(12):4065-4075. doi: 10.1007/s11999-013-3329-4.

4. Lenguerrand E., Whitehouse M.R., Beswick A.D., Toms A.D., Porter M.L., Blom A.W.; National Joint Registry for England, Wales, Northern Ireland and the Isle of Man. Description of the rates, trends and surgical burden associated with revision for prosthetic joint infection following primary and revision knee replacements in England and Wales: an analysis of the National Joint Registry for England, Wales, Northern Ireland and the Isle of Man. BMJ Open. 2017;7(7):e014056. doi: 10.1136/bmjopen-2016-014056.

5. Bonnevialle P., Bonnomet F., Philippe R., Loubignac F., Rubens-Duval B., Talbi A. et al.; SOFCOT. Early surgical site infection in adult appendicular skeleton trauma surgery: a multicenter prospective series. Orthop Traumatol Surg Res. 2012;98(6):684-689. doi: 10.1016/j.otsr.2012.08.002.

6. Berbari E.F., Osmon D.R., Lahr B., Eckel-Passow J.E., Tsaras G., Hanssen A.D. et al. The Mayo prosthetic joint infection risk score: implication for surgical site infection reporting and risk stratification. Infect Control Hosp Epidemiol. 2012;33(8):774-781. doi: 10.1086/666641.

7. Heppert V. Acute Infections After Osteosynthesis. In: European Instructional Lectures: Volume 12, 2012, 13th EFORT Congress, Berlin, Germany. Heidelberg: SpringerVerlag, 2012. pp. 25-31.

8. Keene D.J., Mistry D., Nam J., Tutton E., Handley R., Morgan L. et al. The Ankle Injury Management (AIM) trial: a pragmatic, multicentre, equivalence randomized controlled trial and economic evaluation comparing close contact casting with open surgical reduction and internal fixation in the treatment of unstable ankle fractures in patients aged over 60 years. Health Technol Assess. 2016;20(75):1-158.

9. Oliveira P.R., Carvalho V.C., da Silva Felix C., de Paula A.P., Santos-Silva J., Lima A.L. The incidence and microbiological profile of surgical site infections following internal fixation of closed and open fractures. Rev Bras Ortop. 2016;51(4):396-399. doi: 10.1016/j.rboe.2015.09.012.

10. Shillingford J.N., Laratta J.L., Reddy H., Ha A., Lehman R.A. Jr., Lenke L.G., Fischer C.R. Postoperative Surgical Site Infection After Spine Surgery: An Update From the Scoliosis Research Society (SRS) Morbidity and Mortality Database. Spine Deform. 2018;6(6):634-643. doi: 10.1016/j.jspd.2018.04.004.

11. Warner S.J., Uppstrom T.J., Miller A.O., O’Brien S.T., Salvatore C.M., Widmann R.F., Perlman S.L. Epidemiology of Deep Surgical Site Infections After Pediatric Spinal Fusion Surgery. Spine

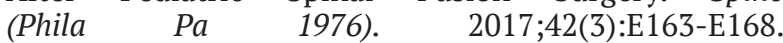
doi: 10.1097/BRS.0000000000001735.

12. Poultsides L.A., Liaropoulos L.L., Malizos K.N. The socioeconomic impact of musculoskeletal infections. J Bone Joint Surg Am. 2010;92(11):e13. doi: 10.2106/JBJS.I.01131.

13. Kurtz S.M., Lau E., Watson H., Schmier J.K., Parvizi J. Economic burden of periprosthetic joint infection in the United States. J Arthroplasty. 2012;27(8 Suppl):61-65.e1. doi: 10.1016/j.arth.2012.02.022.

14. Hernández-Vaquero D., Fernández-Fairen M., Torres A., Menzie A.M., Fernández-Carreira J.M., Murcia-Mazon A. et al. Treatment of periprosthetic infections: an economic analysis. ScientificWorldJournal. 2013;2013:821650. doi: $10.1155 / 2013 / 821650$.

15. Garrido-Gómez J., Arrabal-Polo M.A., Girón-Prieto M.S., Cabello-Salas J., Torres-Barroso J., Parra-Ruiz J. 
Descriptive analysis of the economic costs of periprosthetic joint infection of the knee for the public health system of Andalusia. J Arthroplasty. 2013;28(7):10571060. doi: 10.1016/j.arth.2013.02.012.

16. Klouche S., Sariali E., Mamoudy P. Total hip arthroplasty revision due to infection: a cost analysis approach. Orthop Traumatol Surg Res. 2010;96(2):124-132. doi: 10.1016/j.rcot.2010.02.005.

17. Haenle M., Skripitz C., Mittelmeier W., Skripitz R. Economic impact of infected total knee arthroplasty. ScientificWorldJournal. 2012;2012:196515. doi: $10.1100 / 2012 / 196515$.

18. Lieb E., Hanstein T., Schuerings M., Trampuz A., Perka C. [Reduction of Treatment Duration in Periprosthetic Infection with a Fast-Track Concept Is Economically Not Feasible]. Z Orthop Unfall. 2015;153(6):618-623. doi: 10.1055/s-0035-1557858. (In German).

19. Vanhegan I.S., Malik A.K., Jayakumar P., Ul Islam S., Haddad F.S. A financial analysis of revision hip arthroplasty: the economic burden in relation to the national tariff. J Bone Joint Surg Br. 2012;94(5):619-623. doi: 10.1302/0301-620X.94B5.27073.

20. Alp E., Cevahir F., Ersoy S., Guney A. Incidence and economic burden of prosthetic joint infections in a university hospital: A report from a middle-income country. J Infect Public Health. 2016;9(4):494-498. doi: 10.1016/j.jiph.2015.12.014.

21. Kamath A.F., Ong K.L., Lau E., Chan V., Vail T.P., Rubash H.E. et al. Ouantifying the Burden of Revision Total Joint Arthroplasty for Periprosthetic Infection. J Arthroplasty. 2015;30(9):1492-1497. doi: 10.1016/j.arth.2015.03.035.

22. Romanò C.L., Romanò D., Logoluso N., Meani E. Septic versus aseptic hip revision: how different? J Orthop Traumatol. 2010;11(3):167-174. doi:10.1007/s10195-010-0106-y.

23. Parisi T.J., Konopka J.F., Bedair H.S. What is the Longterm Economic Societal Effect of Periprosthetic Infections After THA? A Markov Analysis. Clin Orthop Relat Res. 2017;475(7):1891-1900. doi: 10.1007/s11999-017-5333-6.

24. Brochin R.L., Phan K., Poeran J., Zubizarreta N., Galatz L.M., Moucha C.S. Trends in Periprosthetic Hip Infection and Associated Costs: A Population-Based Study Assessing the Impact of Hospital Factors Using National Data. J Arthroplasty. 2018;33(7S):S233-S238. doi: 10.1016/j.arth.2018.02.062.

25. Gristina A.G., Naylor P., Myrvik O. Infections from biomaterials and implants: a race for the surface. Med Prog Technol. 1988-1989;14(3-4):205-224.

26. Gristina A.G., Shibata Y., Giridhar G., Kreger A., Myrvik Q.N. The glycocalyx, biofilm, microbes, and resistant infection. Semin Arthroplasty. 1994;5(4):160-170.

27. Dastgheyb S., Parvizi J., Shapiro I.M., Hickok N.J., Otto M. Effect of biofilms on recalcitrance of staphylococcal joint infection to antibiotic treatment. J Infect Dis. 2015;211(4):641-650. doi: 10.1093/infdis/jiu514.

28. Holá V., Růžička F., Votava M. The dynamics of staphylococcus epidermis biofilm formation in relation to nutrition, temperature Effect of biofilms on recalcitrance of staphylococcal joint infection to antibiotic treatment, and time. Scripta Medica Facultatis Medicae Universitatis Brunensis Masarykianae. 2006;79:169-174.

29. Chandki R., Banthia P., Banthia R. Biofilms: A microbial home. J Indian Soc Periodontol. 2011;15(2):111-114. doi: 10.4103/0972-124X.84377.

30. Qin S., Xu K., Nie B., Ji F., Zhang H. Approaches based on passive and active antibacterial coating on titanium to achieve antibacterial activity. J Biomed Mater Res A. 2018;106(9):2531-2539. doi: 10.1002/jbm.a.36413.

31. Romanò C.L., Scarponi S., Gallazzi E., Romanò D., Drago L. Antibacterial coating of implants in orthopaedics and trauma: a classification proposal in an evolving panorama. J Orthop Surg Res. 2015;10:157. doi: 10.1186/s13018-015-0294-5.

32. Moriarty T.F., Grainger D.W., Richards R.G. Challenges in linking preclinical anti-microbial research strategies with clinical outcomes for device-associated infections. Eur Cell Mater. 2014;28:112-128; discussion 128.

33. Alt V. Antimicrobial coated implants in trauma and orthopaedics-A clinical review and risk-benefit analysis. Injury. 2017;48(3):599-607. doi: 10.1016/j.injury.2016.12.011.

34. Chernousova S., Epple M. Silver as antibacterial agent: ion, nanoparticle, and metal. Angew Chem Int Ed Engl. 2013;52(6):1636-1653. doi: 10.1002/anie.201205923.

35. Schmidt-Braekling T., Streitbuerger A., Gosheger G., Boettner F., Nottrott M., Ahrens H., Dieckmann R, Guder W, Andreou D, Hauschild G, Moellenbeck B, Waldstein W, Hardes J. Silver-coated megaprostheses: review of the literature. Eur J Orthop Surg Traumatol. 2017;27(4):483489. doi: 10.1007/s00590-017-1933-9.

36. Hardes J., von Eiff C., Streitbuerger A., Balke M., Budny T., Henrichs M. et al. Reduction of periprosthetic infection with silver-coated megaprostheses in patients with bone sarcoma. J Surg Oncol. 2010;101(5):389-395. doi: 10.1002/jso.21498.

37. Hardes J., Henrichs M.P., Hauschild G., Nottrott M., Guder W., Streitbuerger A. Silver-Coated Megaprosthesis of the Proximal Tibia in Patients With Sarcoma. J Arthroplasty. 2017;32(7):2208-2213. doi: 10.1016/j.arth.2017.02.054.

38. Wafa H., Grimer R.J., Reddy K., Jeys L., Abudu A., Carter S.R., Tillman R.M. Retrospective evaluation of the incidence of early periprosthetic infection with silver-treated endoprostheses in high-risk patients: case-control study. Bone Joint J. 2015;97-B(2):252-257. doi: 10.1302/0301-620X.97B2.34554.

39. Mijnendonckx K., Leys N., Mahillon J., Silver S., Van Houdt R. Antimicrobial silver: uses, toxicity and potential for resistance. Biometals. 2013;26(4):609-621. doi: 10.1007/s10534-013-9645-z.

40. Trentinaglia M.T., Van Der Straeten C., Morelli I., Logoluso N., Drago L., Romanò C.L. Economic Evaluation of Antibacterial Coatings on Healthcare Costs in First Year Following Total Joint Arthroplasty. J Arthroplasty. 2018;33(6):1656-1662. doi: 10.1016/j.arth.2018.01.057.

41. Shirai T., Shimizu T., Ohtani K., Zen Y., Takaya M., Tsuchiya H. Antibacterial iodine-supported titanium implants. Acta Biomater. 2011;7(4):1928-1933. doi: 10.1016/j.actbio.2010.11.036.

42. Inoue D., Kabata T., Ohtani K., Kajino Y., Shirai T., Tsuchiya $H$. Inhibition of biofilm formation on iodine-supported titanium implants. Int Orthop. 2017;41(6):1093-1099. doi: 10.1007/s00264-017-3477-3.

43. Inoue D., Kabata T., Kajino Y., Shirai T., Tsuchiya H. Iodine-supported titanium implants have good antimicrobial attachment effects. J Orthop Sci. 2019;24(3): 548-551. doi: 10.1016/j.jos.2018.10.010.

44. Tsuchiya H., Shirai T., Nishida H., Murakami H., Kabata T., Yamamoto $\mathrm{N}$. et al. Innovative antimicrobial coating of titanium implants with iodine. J Orthop Sci. 2012;17(5):595-604. doi: 10.1007/s00776-012-0247-3.

45. Shirai T., Tsuchiya H., Nishida H., Yamamoto N., Watanabe K., Nakase J. et al. Antimicrobial megaprostheses supported with iodine. J Biomater Appl. 2014;29(4):617-623. doi: 10.1177/0885328214539365. 
46. Kabata T., Maeda T., Kajino Y., Hasegawa K., Inoue D., Yamamoto T. et al. Iodine-supported hip implants: short term clinical results. BioMed Res Int. 2015;2015. Article ID 368124, 6 pages. doi: 10.1155/2015/368124.

47. Schmidmaier G., Wildemann B., Stemberger A., Haas N.P., Raschke M. Biodegradable poly(D,L-lactide) coating of implants for continuous release of growth factors. J Biomed Mater Res. 2001;58(4):449-455. doi: 10.1002/jbm.1040.

48. Fuchs T., Stange R., Schmidmaier G., Raschke M.J. The use of gentamicin-coated nails in the tibia: preliminary results of a prospective study. Arch Orthop Trauma Surg. 2011;131(10):1419-1425. doi: 10.1007/s00402-011-1321-6.

49. Metsemakers W.J., Reul M., Nijs S. The use of gentamicincoated nails in complex open tibia fracture and revision cases: A retrospective analysis of a single centre case series and review of the literature. Injury. 2015;46(12): 2433-2437. doi: 10.1016/j.injury.2015.09.028.

50. Schmidmaier G., Kerstan M., Schwabe P., Südkamp N., Raschke M. Clinical experiences in the use of a gentamicin-coated titanium nail in tibia fractures. Injury. 2017;48(10):2235-2241. doi: 10.1016/j.injury.2017.07.008.

51. Schmitz F.J., Verhoef J., Fluit A.C. Prevalence of aminoglycoside resistance in 20 European university hospitals participating in the European SENTRY Antimicrobial Surveillance Programme. Eur J Clin Microbiol Infect Dis. 1999;18(6):414-421.

52. Drago L., Boot W., Dimas K., Malizos K., Hänsch G.M., Stuyck J. et al. Does implant coating with antibacterialloaded hydrogel reduce bacterial colonization and biofilm formation in vitro? Clin Orthop Relat Res. 2014;472(11): 3311-3323. doi: 10.1007/s11999-014-3558-1.

53. Romanò C.L., De Vecchi E., Bortolin M., Morelli I., Drago L. Hyaluronic Acid and Its Composites as a Local Antimicrobial/Antiadhesive Barrier. J Bone Jt Infect. 2017;2(1):63-72. doi: 10.7150/jbji.17705.

54. Ardizzoni A., Neglia R.G., Baschieri M.C., Cermelli C., Caratozzolo M., Righi E. et al. Influence of hyaluronic acid on bacterial and fungal species, including clinically relevant opportunistic pathogens. J Mater Sci Mater Med. 2011;22(10):2329-2338. doi: 10.1007/s10856-011-4408-2.

55. Pavesio A., Renier D., Cassinelli C., Morra M. Antiadhesive surfaces through hyaluronan coatings. Med Device Technol. 1997;8(7):20-21, 24-27.

56. Morra M., Cassineli C. Non-fouling properties of polysaccharide-coated surfaces. I Biomater Sci Polym Ed. 1999;10(10):1107-1124.
57. Giavaresi G., Meani E., Sartori M., Ferrari A., Bellini D., Sacchetta A.C. et al. Efficacy of antibacterial-loaded coating in an in vivo model of acutely highly contaminated implant. Int Orthop. 2014;38(7):1505-1512. doi: 10.1007/s00264-013-2237-2.

58. Boot W., Vogely H.Ch., Nikkels P.G.J., Dhert W., Gawlitta D. Local prophylaxis of implant-related infections using a hydrogel as carrier. Eur Cell Mater. 2015;30:19.

59. Boot W., Gawlitta D., Nikkels P.G.J., Pouran B., van Rijen M.H.P., Dhert W.J.A, Vogely H.C. Hyaluronic Acid-Based Hydrogel Coating Does Not Affect Bone Apposition at the Implant Surface in a Rabbit Model. Clin Orthop Relat Res. 2017;475(7):1911-1919. doi: 10.1007/s11999-017-5310-0.

60. Romanò C.L., Malizos K., Capuano N., Mezzoprete R., D’Arienzo M., Van Der Straeten C. et al. Does an Antibiotic-Loaded Hydrogel Coating Reduce Early PostSurgical Infection After Joint Arthroplasty? J Bone Jt Infect. 2016;1:34-41. doi: 10.7150/jbji.15986.

61. Malizos K., Blauth M., Danita A., Capuano N., Mezzoprete R., Logoluso N. et al. Fast-resorbable antibiotic-loaded hydrogel coating to reduce post-surgical infection after internal osteosynthesis: a multicenter randomized controlled trial. J Orthop Traumatol. 2017;18(2):159-169. doi: 10.1007/s10195-017-0442-2.

62. Capuano N., Logoluso N., Gallazzi E., Drago L., Romanò C.L. One-stage exchange with antibacterial hydrogel coated implants provides similar results to two-stage revision, without the coating, for the treatment of peri-prosthetic infection. Knee Surg Sports Traumatol Arthrosc. 2018;26(11):3362-3367. doi: 10.1007/s00167-018-4896-4.

63. Graves N., Wloch C., Wilson J., Barnett A., Sutton A., Cooper N. et al. A cost-effectiveness modelling study of strategies to reduce risk of infection following primary hip replacement based on a systematic review. Health Technol Assess. 2016;20(54):1-144. doi: 10.3310/hta20540.

64. Shearer D.W., Youm J., Bozic K.J. Short-term complications have more effect on cost-effectiveness of THA than implant longevity. Clin Orthop Relat Res. 2015;473(5): 1702-1708. doi: 10.1007/s11999-014-4110-z.

65. Romanò C.L., Tsuchiya H., Morelli I., Battaglia A.G., Drago L. Antibacterial coating of implants: are we missing something? Bone Joint Res. 2019;8(5):199-206. doi: 10.1302/2046-3758.85.BJR-2018-0316.

\section{AUTHORS' AFFILATIONS:}

Carlo Luca Romanò - MD, Orthopaedic Consultant, Studio Medico Associato Cecca-Romanò, Milan, Italy; Director, Romano Institute, Tirane, Albania

Svelana Bozhkova - Dr. Sci. (Med.), Head of the Research Department of Prevention and Treatment of Wound Infection and Department of Clinical Pharmacology, Vreden Russian Research Institute of Traumatology and Orthopedics, St. Petersburg, Russian Federation

Vasilii Artyukh - Cand. Sci. (Med.), Head of Department, Vreden Russian Research Institute of Traumatology and Orthopedics, St. Petersburg, Russian Federation

Delia Romanò - MD, Consultant, Studio Medico Associato Cecca-Romanò, Milan, Italy

Hiroyuki Tsuchiya - MD, PhD, Professor and Chairman, Department of Orthopaedic Surgery, Graduate School of Medical Sciences, Kanazawa University, Kanazawa, Japan

Lorenzo Drago - PhD, Professor, Clinical Microbiology Department of Biomedical Sciences for Health, University of Milan, Milan, Italy 